\title{
Checklist of citrus mites (Acari) of Egypt
}

\author{
A. S. Abdelgayed; M. W. Negm; S. A. Eraky and T. Y. Helal
}

Dept. of Plant Protection, Fac. of Agric., Assiut Univ., Assiut, Egypt.

\begin{abstract}
Mites inhabiting citrus orchards in Egypt were listed. The checklist, compiled from a survey of published literature, contains 149 mite species representing 39 families. It is expected that the number of the Egyptian mite species inhabiting different citrus cultivations will increase as comprehensive surveys continue. The most diverse order, Prostigmata, is represented by 95 species followed by, Mesostigmata, with 37 species. The families with the most citrus mite species known from Egypt are the Phytoseiidae and Tetranychidae with 18 and 12 species.
\end{abstract}

Key words: Acari; mites; diversity; Egypt; taxonomy.

\section{INTRODUCTION}

Citrus is the most popular fruit to Egyptians. Egypt is considered the second largest citrus-growing area $(137,370$ he) in Africa after Nigeria (732,000 he), where orange, mandarin, lime, lemon and grapefruit are cultivated (FAOSTAT, 2008). Mites play an important role in citrus production whether as pests or beneficials. In Egypt, the mite fauna of citrus orchards is still not completely known. Few comprehensive surveys concerning mites associated with citrus were conducted (Zaher et al., 1970; Rasmy et al., 1972; Abo-Korah, 1980-1981; Zaher, 1984a \& b, 1986; Kandeel \& Nassar, 1986 and Rahil \& Abd-El-Halim, 2000) which are important addition to the literature.

There is no single source compiling mite taxa reported from citrus orchards in Egypt. Here the authors present a list of citrus mites collected from Egypt as a first work aiming at providing a foundation for future studies on Egyptian citrus mites.

\section{MATERIALS AND METHODS}

The list was prepared from several data sources. The authors surveyed the original literature dealing with the Egyptian mite fauna of citrus orchards (sweet orange, mandarin, lemon, grapefruit, kumquat, lime) including soil, litter and debris beneath trees. Data for the list include the mite species and its author(s) in addition to distribution records and habitats. Species from unpublished theses were not included in the present work. Families, genera and species of citrus mites are presented in alphabetical order.

\section{RESULTS AND DISCUSSION}

The mite fauna of citrus orchards was found belonging to the orders Mesostigmata (10 families, 37 species), Prostigmata (20 families, 95 species), Cryptostigmata (6 families, 12 species) and Astigmata (3 families, 5 species).

\section{ORDER MESOSTIGMATA}

\section{Family: Ameroseiidae Evans}

\section{Kleemannia kosi El Badry, Nasr \& Hafez}

Habitats and distribution: Debris under orange in Qena and Aswan (Zaher, 1986).

\section{Kleemannia plumosus Oudemans}

Habitats and distribution: Leaves of lime in Fayoum (Sennores) (Rahil \& Abd-El- Halim, 2000).

\section{Family: Ascidae Voigts \& Oudemans}

\section{Arctoseius bilinear Nasr}

Habitats and distribution: Debris under sweet orange, Citrus sinensis (L.) Osbeck in Giza (Zaher, 1986); leaves of mandarin in Fayoum (Sennores) (Rahil \& Abd-El-Halim, 2000).

\section{Gamasellodes zaheri Nasr}

Habitats and distribution: Debris under citrus trees in Beheira and Qalyubia (Zaher, 1986).

\section{Proctolaelaps bickleyi (Bram.)}

Habitats and distribution: Litter under citrus trees in Giza and Assiut (Sahel Saleem, Badary) (Zaher et al., 1970); leaves, fruits and litter of Baladi and Navel orange in Lower Egypt (Rasmy et al., 1972).

\section{Proctolaelaps hypudaei (Oudemans)}

Habitats and distribution: Leaves, fruits and litter of mandarin, Baladi and Navel orange in Lower Egypt (Rasmy et al., 1972).

\section{Proctolaelaps orientalis Nasr}

Habitats and distribution: Debris under citrus trees in Giza and Beni Suef (Zaher, 1986).

\section{Family: Blattisociidae Garman}

\section{Cheiroseius nepalensis (Evans and Hyatt)}

Habitats and distribution: Debris under citrus trees in Giza (Zaher, 1986).

\section{Lasioseius africanus Nasr}

Habitats and distribution: Debris under citrus trees in Giza and Sohag (Zaher, 1986). 
10. Lasioseius peritremus Nasr \& Abou-Awad

Habitats and distribution: Debris under citrus trees in Beni Suef (Zaher, 1986).

\section{Family: Digamasellidae Evans}

11. Dendrolaelaps aegypticus Metwally \& Mersal Habitats and distribution: Debris under citrus trees in Giza (Zaher, 1986).

\section{Family: Laelapidae Berlese}

\section{Hypoaspis koseii Hafez, El Badry \& Nasr}

Habitats and distribution: Soil under orange in Assiut (Zaher, 1986).

\section{Family Macrochelidae Vitzthum}

13. Macrocheles punctata Hafez, El-Badry \& Nasr Habitats and distribution: Leaves of sweet orange in Fayoum (Sennores) (Rahil \& Abd-El-Halim, 2000).

\section{Family: Ologamasidae Ryke}

\section{Gamasiphis denticus Hafez \& Nasr}

Habitats and distribution: Leaves of mandarin in Fayoum (Sennores) (Rahil \& Abd-El-Halim, 2000).

\section{Gamasiphis parpulchellus Nasr \& Mersal}

Habitats and distribution: Debris under citrus trees in Giza and Qalyubia (Zaher, 1986).

\section{Sessiluncus aegypticus Nasr \& Afifi}

Habitats and distribution: Debris under citrus trees in Minya and Qalyubia (Zaher, 1986).

\section{Family: Pachylaelapidae Berlese}

\section{Zygoseius badrii Hafez \& Nasr}

Habitats and distribution: Soil under $C$. sinensis in Qalyubia (Zaher, 1986).

Family: Phytoseiidae Berlese

18. Amblyseiella setosa Muma (=Amblyseius denmarki El-Borolossy- Chant \& McMurtry, 2007)

Habitats and distribution: Debris under citrus trees in Qalyubia (Zaher, 1986).

19. Amblyseius swirskii Athias-Henriot (=Amblyseius enab El-Badry-Ramadan et al., 2009) Habitats and distribution: Leaves and fruits of orange, mandarin, lemon, kumquat and grapefruit in Lower Egypt (Rasmy et al., 1972); citrus in Ismailia and Dakahlia (Zaher, 1986); cosmopolitan in citrus orchards (Kandeel \& Nassar, 1986); leaves of mandarin in Fayoum (Sennores) (Rahil \& Abd-ElHalim, 2000).

\section{Amblyseius sp.}

Habitats and distribution: Citrus trees in Giza (Zaher et al., 1970); orange orchards in Giza and Tahreer (Rasmy, 1970); leaves of Baladi orange in Lower Egypt (Rasmy et al., 1972).
21. Cydnoseius negevi (Swirski \& Amitai) (=Typhlodromus medanicus El-Badry-Chant \&Yoshida-Shaul, 1986; =Typhlodromus schusteri Yousef \& El Brollosy-Kanouh et al., 2012).

Habitats and distribution: Citrus in Qalyubia and Beheira (Zaher 1986).

22. Euseius scutalis (Athias-Henriot) (=Amblyseius gossipi El-Badry-Wyoski \& Bolland, 1983)

Habitats and distribution: Citrus orchards in Qalyubia (Kandeel \& Nassar, 1986; Kandeel et al., 1986); leaves and branches of sweet orange and mandarin in Fayoum (Sennores) (Rahil \& Abd-ElHalim, 2000).

\section{Iphiseius degenerans (Berlese)}

Habitats and distribution: Leaves of citrus in Giza (Zaher, 1986).

24. Neoseiulus aegyptocitri (Kandeel \& ElHalawany)

Habitats and distribution: Citrus orchards in Qalyubia (Kandeel \& El-Halawany, 1986).

\section{Neoseiulus longispinosus (Evans)}

Habitats and distribution: Branches of sweet orange in Fayoum (Sennores) (Rahil \& Abd-El-Halim, 2000).

26. Paraseiulus talbii (Athias-Henriot) (=Typhlodromus tetramedius Zaher \& ShehataChant \& Yoshia-Shaul, 1982).

Habitats and distribution: Citrus trees in Giza (ElBadry, 1967); citrus leaves in Gharbia (Samannoud) and Fayoum (Zaher \& Shehata, 1970); cosmopolitan in citrus orchards (Kandeel \& Nassar, 1986).

27. Proprioseiopsis messor (Wainstein) (=Amblyseius lindquisti Schuster \& PritchardAbbasova, 1972).

Habitats and distribution: Debris under citrus trees in Ismailia, Monufia and Dakahlia (Zaher, 1986).

\section{Seiulus sp.}

Habitats and distribution: Citrus trees in Beheira (Wadi El Natrun), Tahreer and Port Said (Zaher et al., 1970).

\section{Typhlodromus (Anthoseius) citri Hassan \& Romeih}

Habitats and distribution: Leaves and debris of citrus in Fayoum (Romeih et al., 2005).

30. Typhlodromus (Anthoseius) egypticus El-Badry (=Typhlodromus mangiferus Zaher \& El-BorolossyAbo-Shnaf \& Moraes, 2014).

Habitats and distribution: Citrus in South Sinai (Wadi Firan, Wady El-Tarfa, St. Cathrin) (Zaher, 1984b).

31. Typhlodromus (Anthoseius) lataniae El-Badry Habitats and distribution: Leaves of citrus in 
Alexandria (El-Badry, 1968).

32. Typhlodromus (Typhlodromus) athiasae Porath \& Swirski (=Typhlodromus pelargonicus El-BadryAbbasova, 1972; Chant \& Yoshida-Shaul, 1987).

Habitats and distribution: Leaves and debris of citrus in Giza and Monufia (Zaher, 1986); leaves and branches of sweet orange, mandarin and lime in Fayoum (Sennores) (Rhahil \& Abd-El-Halim, 2000).

33. Typhlodromus (Typhlodromus) kadii Kandeel \& El-Halawany

Habitats and distribution: Citrus orchards in Fayoum and Giza (Kandeel \& El-Halawany, 1985; Kandeel \& Nassar, 1986).

\section{Typhlodromus (Typhlodromus) pyri Scheuten} Habitats and distribution: Cosmopolitan in citrus orchards (Zaher et al., 1970); orange orchards in Giza and Cairo (Rasmy, 1970); leaves of Valencia orange in Lower Egypt (Rasmy et al., 1972).

\section{Typhlodromus sp.}

Habitats and distribution: Citrus orchards in Giza, Alexandria and Tahreer (Zaher et al., 1970).

Family: Uropodidae Kramer

36. Nenteria hypotichus El-Borolossy \& ElBanhawy

Habitats and distribution: Lemon orchards (ElBanhawy et al., 1997).

37. Unidentified genus and species

Habitats and distribution: Citrus orchards in Qalyubia (Zaher et al., 1970); litter under mandarin in Lower Egypt (Rasmy et al., 1972).

\section{ORDER PROSTIGMATA}

\section{Family: Bdellidae Dugès}

\section{Cyta latirostris (Hermann)}

Habitats and distribution: Litter under citrus trees in Giza and Sharkeia (Kandeel \& Nassar, 1986).

\section{Spinibdella bifurcata Ateyo}

Habitats and distribution: Litter under citrus trees in Upper Egypt (Kandeel \& Nassar, 1986); leaves and branches of mandarin and lime in Fayoum (Sennores) (Rahil \& Abd-El-Halim, 2000).

\section{Unidentified genus and species}

Habitats and distribution: Leaves of Navel and Baladi orange in Lower Egypt (Rasmy et al., 1972).

\section{Family: Caligonellidae Grandjean}

\section{Molothrognathus minutus Soliman}

Habitats and distribution: Debris under citrus trees in Giza and Beni Suef (Zaher, 1986).

\section{Family: Camerobiidae Southcott}

\section{Neophyllobius aegyptium Soliman \& Zaher}

Habitats and distribution: Leaves of Navel orange in Lower Egypt (Rasmy et al., 1972); citrus trees in Giza (Zaher, 1986).

\section{Neophyllobius citri Soliman \& Zaher}

Habitats and distribution: Citrus orchards in Giza and Assiut (Sahel Saleem, Badary) (Zaher et al., 1970); leaves of Baladi orange in Lower Egypt (Rasmy et al., 1972); citrus trees in Aswan (Zaher, 1986); citrus trees in Alexandria and Aswan (Kandeel \& Nassar, 1986).

\section{Neophyllobius mangiferus Zaher \& Gomaa}

Habitats and distribution: Citrus trees in Sharqia, Tahreer and Beheira (Kandeel \& Nassar, 1986); leaves of lime in Fayoum (Sennores) (Rahil \& AbdEl-Halim, 2000).

\section{Family: Cheyletidae Leach}

45. Acaropsella volgini Gerson (=Acaropsis aegyptiaca Wafa \& Soliman-Negm \& Mesbah, 2014) Habitats and distribution: Fallen citrus fruits and debris in Tahreer and Giza (Wafa \& Soliman, 1968).

\section{Acaropsellina docta (Berlese)}

Habitats and distribution: Citrus trees in Giza (Zaher et al., 1970).

\section{Acaropsellina sollers (Rohdendorf)}

Habitats and distribution: Citrus trees in Sharqia (Kandeel \& Nassar, 1986); Citrus aurantium L. in Giza and Fayoum (Romeih et al., 2010).

48. Cheletogenes ornatus (Canestrini \& Fanzago) Habitats and distribution: Citrus trees (El-Badry \& Zaher, 1960); citrus trees in Alexandria, Beheira (Wadi El Natrun) and Assiut (Sahel Saleem, Badary) (Zaher et al., 1970); leaves and fruits of orange, mandarin, lemon, kumquat and grapefruit in Lower Egypt (Rasmy et al., 1972); leaves of lime, orange and mandarin in Assiut (Salman et al., 1975); citrus trees (Rizk et al., 1978-1979); cosmopolitan in citrus orchards (Kandeel \& Nassar, 1986); leaves and branches of sweet orange and mandarin in Fayoum (Sennores) (Rahil \& Abd-El-Halim, 2000); Citrus buds in Giza (Embaba) (Negm \& Mesbah, 2014).

\section{Cheyletus malaccensis Oudemans}

Habitats and distribution: Branches of sweet orange and mandarin in Fayoum (Sennores) (Rahil \& AbdEl-Halim, 2000).

\section{Eutogenes punctata Zaher \& Soliman}

Habitats and distribution: Citrus trees (Zaher \& Soliman, 1965); citrus in Giza, Beni Suef and Qalyubia (Zaher, 1986). 


\section{Hemicheyletia bakeri Ehara}

Habitats and distribution: Citrus trees in Alexandria, Assiut (Sahel Saleem, Badary) and Beheira (Wadi El Natrun) (Zaher et al., 1970); leaves and fruits of orange, mandarin, lemon, kumquat and grapefruit in Lower Egypt (Rasmy et al., 1972); citrus in North Sinai (Areish, Rafah, El-Sheikh Zewaid), South Sinai (Dahab, Newaibei, Taba, Sharm El-Sheikh) (Zaher, 1984b); leaves of sweet orange in Fayoum (Sennores) (Rahil \& Abd-El-Halim, 2000).

\section{Family: Cunaxidae Sig Thor}

\section{Cunaxa capreolus (Berlese)}

Habitats and distribution: Branches of sweet orange in Fayoum (Sennores) (Rahil \& Abd-El-Halim, 2000).

\section{Cunaxa setirostris (Hermann)}

Habitats and distribution: Citrus orchards in Giza (Zaher et al., 1970); leaves and fruits of Navel and Baladi orange in Lower Egypt (Rasmy et al., 1972); citrus orchards in Dakahlia, Sharkeia and Damietta (Zaher, 1986); leaves of citrus and litter under citrus trees in the Nile Delta (Kandeel \& Nassar, 1986).

54. Neocunaxoides fayoumi Romeih \& Abo-Shnaf Habitats and distribution: Debris of Citrus spp. in Fayoum (Romeih \& Abo-Shnaf, 2006).

\section{Family: Eriophyidae Nalepa}

\section{Aceria sheldoni (Ewing)}

Habitats and distribution: Citrus sp., sweet orange and lemon in Alexandria (Zaher, 1984a); citrus buds in North Sinai (Areish) (Zaher, 1984b).

\section{Phyllocoptruta citri Soliman \& Abou-Awad} Habitats and distribution: Citrus spp., leaves and fruits of Navel and Valencia orange and mandarin (Soliman \& Abou-Awad, 1978); citrus trees in Beheira and Nile Delta (Zaher, 1984a).

\section{Phyllocoptruta oleivora (Ashmead)}

Habitats and distribution: Citrus trees in Alexandria and North Sinai (Areish, Rafah) (Zaher et al., 1970); leaves of Navel, Valencia, mandarin and Baladi lemon (Rasmy et al., 1972); orange trees in Kafr ElSheikh, Dakahlia, Beheira and Alexandria (Zaher, 1984a).

\section{Family: Eupalopsellidae Willmann}

\section{Eupalopsellus olearius Zaher \& Gomaa}

Habitats and distribution: Citrus trees in Sharqia, Qalyubia, Gharbia, Monufia, Beheira, Alexandria, Giza and Beni suef (Kandeel \& Nassar, 1986).

\section{Exothorhis aegyptium Kandeel \& Nassar}

Habitats and distribution: Citrus trees in Sharqia (Kandeel \& Nassar, 1986).

\section{Saniosulus nudus Summers}

Habitats and distribution: Citrus trees in Giza (Zaher et al., 1970); leaves and fruits of orange, mandarin, lemon, kumquat and grapefruit in Lower Egypt (Rasmy et al., 1972); citrus trees in Dakahlia, Damietta and Alexandria (Kandeel \& Nassar, 1986).

\section{Family: Eupodidae Koch}

61. Egypteupodes strandtmanni (Abou-Awad)

Habitats and distribution: Soil under citrus trees in Monufia and Giza (Zaher, 1986).

\section{Eupodes niloticus Abou-Awad \& El-Bagoury}

Habitats and distribution: Leaves and branches of sweet orange, mandarin and lime in Fayoum (Sennores) (Rahil \& Abd-El-Halim, 2000).

\section{Eupodes sp.}

Habitats and distribution: Citrus trees in Port Said (Zaher et al., 1970); litter under Baladi lemon in Lower Egypt (Rasmy et al., 1972).

\section{Family: Microdispidae Cross}

\section{Brennandania silvestris Jacob}

Habitats and distribution: Soil of citrus orchards in Monufia (Abo-Korah, 1980-1981).

\section{Family: Pyemotidae Oudemans}

65. Unidentified genus and species

Habitats and distribution: Litter under Baladi lemon in Lower Egypt (Rasmy et al., 1972).

\section{Family: Pygmephoridae Cross}

\section{Bakerdania centriger (Cooreman)}

Habitats and distribution: Soil of citrus orchards in Monufia (Abo-Korah, 1980-1981).

\section{Bakerdania citri Zaher \& Kandeel}

Habitats and distribution: Soil under citrus in Sharkeia (Zaher, 1986).

\section{Bakerdania gracilis (Krczal)}

Habitats and distribution: Soil of citrus orchards in Monufia (Abo-Korah, 1980-1981).

\section{Bakerdania haarloevi Krezal}

Habitats and distribution: Soil of citrus orchards in Monufia (Abo-Korah, 1980-1981).

\section{Bakerdania latipilosus Rack.}

Habitats and distribution: Soil of citrus orchards in Monufia (Abo-Korah, 1980-1981).

\section{Bakerdania tarsalis (Hirst)}

Habitats and distribution: Soil of citrus orchards in Monufia (Abo-Korah, 1980-1981). 


\section{Bakerdania sp.}

Habitats and distribution: Soil of citrus orchards in Monufia (Abo-Korah, 1980-1981).

73. Pediculaster mesembrinae Can.

Habitats and distribution: Soil of citrus orchards in Monufia (Abo-Korah, 1980-1981).

\section{Pygmephorus ursulae Mah.}

Habitats and distribution: Soil of citrus orchards in Monufia (Abo-Korah, 1980-1981).

Family: Raphignathidae Kramer

\section{Raphignathus bakeri Zaher \& Gomaa}

Habitats and distribution: Lime trees in Beheira, Gharbia and Fayoum (Zaher \& Gomaa, 1979).

76. Raphignathus niloticus Rakha \& Mohamed Habitats and distribution: Leaves of lime in Fayoum (Sennores) (Rahil \& Abd-El-Halim, 2000).

\section{Family: Scutacaridae Oudemans}

\section{Imparipes tataricus Sev.}

Habitats and distribution: Soil of citrus orchards in Monufia (Abo-Korah, 1980-1981).

\section{Imparipes sp.}

Habitats and distribution: Soil of citrus orchards in Monufia (Abo-Korah, 1980-1981).

\section{Scutacarus longitarsus Berlese}

Habitats and distribution: Soil of citrus orchards in Monufia (Abo-Korah, 1980-1981).

80. Scutacarus quadrangularis Paol

Habitats and distribution: Soil of citrus orchards in Monufia (Abo-Korah, 1980-1981).

\section{Scutacarus spinosus Storkán}

Habitats and distribution: Soil of citrus orchards in Monufia (Abo-Korah, 1980-1981).

\section{Scutacarus suborbiculatus Rack}

Habitats and distribution: Soil of citrus orchards in Monufia (Abo-Korah, 1980-1981).

\section{Scutacarus sp.}

Habitats and distribution: Soil of citrus orchards in Monufia (Abo-Korah, 1980-1981).

\section{Family: Siteroptidae Mahunka}

\section{Siteroptes priscus Krczal}

Habitats and distribution: Soil of citrus orchards in Monufia (Abo-Korah, 1980-1981).

\section{Siteroptes sp.}

Habitats and distribution: Soil of citrus orchards in Monufia (Abo-Korah, 1980-1981).

\section{Family: Stigmaeidae Oudemans}

86. Agistemus exsertus Gonzalez

Habitats and distribution: Cosmopolitan on citrus trees (Zaher et al., 1970; Kandeel \& Nassar, 1986); leaves and fruits of orange, mandarin, lemon, kumquat and grapefruit in Lower Egypt (Rasmy et al. 1972); leaves of lime, orange and mandarin in Assiut (Salman et al., 1975); citrus trees (Rizk et al., 19781979); leaves and branches of sweet orange, mandarin and lime in Fayoum (Sennores) (Rahil \& Abd-El-Halim, 2000).

\section{Agistemus fleschneri Summers}

Habitats and distribution: Citrus sinensis in Giza (Zaher \& El-Badry, 1962).

\section{Apostigmaeus navicella Grandjean}

Habitats and distribution: Citrus in North Sinai (Areish) (Zaher, 1984b).

\section{Mediolata aegyptiaca (Soliman \& Zaher)}

Habitats and distribution: Leaves and fruits of orange, mandarin, lemon, kumquat and grapefruit in Lower Egypt (Rasmy et al., 1972).

\section{Mediolata pini (Canestrini)}

Habitats and distribution: Leaves and fruits of orange, mandarin, lemon, kumquat and grapefruit in Lower Egypt (Rasmy et al., 1972).

91. Stigmaeus elongatus Berlese (=Stigmaeus luteus Summers-Khanjani \& Ueckermann, 2002).

Habitats and distribution: Litter under Baladi lemon in Lower Egypt (Rasmy et al., 1972).

Family: Tarsonemidae Canestrini \& Fanzago

\section{Diadalotarsonemus krantzi Zaher \& Kandeel}

Habitats and distribution: Citrus buds in Sharqia (Zaher, 1986).

\section{Diadalotarsonemus rodriguezi Zaher \&} Kandeel

Habitats and distribution: Leaves of citrus in Qalyubia (Zaher 1986); leaves and branches of sweet orange, mandarin and lime in Fayoum (Sennores) (Rahil \& Abd-El-Halim, 2000).

\section{Diadalotarsonemus sp.}

Habitats and distribution: Citrus orchards in Monufia (Zaher et al., 1970); mandarin in Lower Egypt (Rasmy et al., 1972).

\section{Tarsonemus bilobatus Suski}

Habitats and distribution: Soil of citrus orchards in Monufia (Abo-Korah, 1980-1981).

96. Tarsonemus idaeus Suski

Habitats and distribution: Soil of citrus orchards in Monufia (Abo-Korah, 1980-1981). 


\section{Tarsonemus smithi Ewing}

Habitats and distribution: Leaves and fruits of Navel orange and Baladi lemon in Lower Egypt (Rasmy et al., 1972).

\section{Tarsonemus sp.}

Habitats and distribution: Cosmopolitan in citrus orchards (Zaher et al., 1970); soil of citrus orchards in Monufia (Abo-Korah, 1980-1981).

\section{Family: Tenuipalpidae Berlese}

\section{Brevipalpus californicus (Banks)}

Habitats and distribution: Cosmopolitan in citrus orchards (Zaher et al., 1970); leaves, fruits and buds of orange, mandarin, lemon, kumquat and grapefruit in Lower Egypt (Rasmy et al., 1972); C. aurantium in Tahreer, Beheira (Wadi El Natrun), Giza, Qalyubia and Fayoum (Zaher, 1984a); citrus in Qalyubia (ElHalawany, 1991); C. aurantium in Giza and Citrus spp. in Qalyubia (Tukh), Beheira and Dakahlia (Halawa \& Fawzy, 2014).

\section{Brevipalpus jordani Dosse}

Habitats and distribution: Citrus orchards (Dosse, 1972 in Vacante, 2010).

\section{Brevipalpus lewisi McGregor}

Habitats and distribution: Leaves of mandarin and Baladi lemon in Lower Egypt (Rasmy et al., 1972); Citrus spp. in Monufia (El Bagour) (Halawa \& Fawzy, 2014).

\section{Brevipalpus noranae Halawa \& Fawzy}

Habitats and distribution: Mixed plantations of $C$. aurantium and Malus domestica Borkh. in Qalyubia (Tukh) (Halawa \& Fawzy, 2014).

\section{Brevipalpus obovatus Donnadieu}

Habitats and distribution: Citrus trees in Giza (Zaher \& El-Badry, 1964); cosmopolitan in citrus orchards (Zaher et al., 1970); leaves of Baladi orange in Lower Egypt (Rasmy et al., 1972); C. aurantium in Cairo, Giza, Fayoum, Port Said, Assiut and Gharbia (Zaher, 1984a); citrus in North Sinai (Areish) and Red Sea (Safagah) (Zaher, 1984b); leaves and branches of sweet orange, mandarin and lime in Fayoum (Sennores) (Rahil \& Abd-El-Halim, 2000).

\section{Brevipalpus olearius Sayed}

Habitats and distribution: Leaves of sweet orange in Fayoum (Sennores) (Rahil \& Abd-El-Halim, 2000).

\section{Brevipalpus phoenicis (Geijskes)}

Habitats and distribution: Cosmopolitan in citrus orchards (Zaher et al., 1970); leaves of mandarin and Baladi lemon in Lower Egypt (Rasmy et al., 1972); leaves of lime, orange and mandarin in Assiut (Salman et al., 1975); Citrus spp. in Cairo, Sharkeia, Qalyubia, Giza, Fayoum, Gharbia, Port Said and Minya (Zaher, 1984a); leaves and branches of sweet orange, mandarin and lime (Rahil \& Abd-El-Halim, 2000); Citrus spp. in Giza (Halawa \& Fawzy, 2014).

\section{Cenopalpus lanceolatisetae (Attiah)}

Habitats and distribution: Leaves of sweet orange and mandarin in Fayoum (Sennores) (Rahil \& AbdEl-Halim, 2000).

\section{Cenopalpus pulcher (Canestrini \& Fanzago)}

Habitats and distribution: Leaves and fruits of Navel, Sukkari and Baladi lemon in Lower Egypt (Rasmy et al., 1972).

\section{Tenuipalpus granati Sayed}

Habitats and distribution: Leaves of mandarin and lime in Fayoum (Sennores) (Rahil \& Abd-El-Halim, 2000).

\section{Family: Tetranychidae Donnadieu}

\section{Bryobia cristata (Dugès)}

Habitats and distribution: Citrus aurantium in Giza and Fayoum (Romeih et al., 2010).

\section{Eutetranychus africanus (Tucker)}

Habitats and distribution: Orange in Giza and Fayoum (Attiah, 1967).

\section{Eutetranychus banksi (McGregor)}

Habitats and distribution: Orange trees (Mohamed, 1965).

\section{Eutetranychus citri Attiah}

Habitats and distribution: Lime trees in Qalyubia (Abu-Zaabal) (Attiah, 1967).

\section{Eutetranychus orientalis (Klein)}

Habitats and distribution: Leaves and fruits of citrus in Upper and Lower Egypt (Sayed, 1942 \& 1946); cosmopolitan in citrus trees (Attiah, 1967); cosmopolitan in citrus orchards (Zaher et al.,1970); orange orchards in Giza and Tahreer (Rasmy, 1970); leaves and fruits of orange, mandarin, lemon, kumquat and grapefruit in Lower Egypt (Rasmy et al., 1972); leaves of lime, orange and mandarin in Assiut (Salman et al., 1975); C. aurantium in Giza and Beheira (Zaher et al., 1982); C. aurantium in Giza, Beni Suef, Qalyubia and Beheira and $C$. aurantium var. amara L. in Beni Suef (Zaher, 1984a); citrus in North Sinai (Areish), South Sinai (Wadi Firan, Wadi El-Tarfa, El-Tor) and Red Sea (RasGhareb) (Zaher, 1984b); leaves and branches of sweet orange, mandarin and lime in Fayoum (Sennores) (Rahil \& Abd-El-Halim, 2000).

\section{Eutetranychus pantopus (Berlese)}

Habitats and distribution: Citrus sp. (Sayed, 1942).

\section{Eutetranychus pyri Attiah}

Habitats and distribution: Citrus aurantium in Beni Suef (Zaher et al., 1982; Zaher, 1984a). 
116. Oligonychus mangiferus (Rahman \& Sapra) Habitats and distribution: Citrus orchards in Giza (Zaher et al., 1970).

\section{Tetranychus cinnabarinus (Boisduval)}

Habitats and distribution: Leaves of orange, mandarin, lemon, kumquat and grapefruit in Lower Egypt (Rasmy et al., 1972).

\section{Tetranychus cucurbitacearum (Sayed)}

Habitats and distribution: Citrus aurantium in Beheira (Zaher et al., 1982); lemon in North Sinai (Areish, Rafah), South Sinai (El-Tor) and Red Sea (Ras-Ghareb) (Zaher, 1984b).

\section{Tetranychus neocaledonicus André}

Habitats and distribution: Citrus trees in Beheira (Attiah, 1969).

\section{Tetranychus urticae Koch}

Habitats and distribution: Cosmopolitan in citrus orchards (Zaher et al., 1970); Citrus aurantium in Beni Suef, Minya, Assiut and Sohag (Zaher, 1984a); leaves and branches of sweet orange, mandarin and lime in Fayoum (Sennores) (Rahil \& Abd-El-Halim, 2000).

\section{Family: Tuckerellidae Baker \& Pritchard 121. Tuckerella nilotica Zaher \& Rasmy}

Habitats and distribution: Citrus in Assiut (Sahel Saleem, Badary) (Zaher et al., 1970); citrus trees, $C$. aurantium in Assiut and Aswan (Kom-Ombo) (Zaher, 1984a).

\section{Family: Tydeidae Kramer}

122. Loryia mali (Oudemans)

Habitats and distribution: Citrus in Assiut (Sahel Saleem) and New Valley (Zaher et al., 1970); leaves of Baladi orange (Rasmy et al., 1972).

\section{Paralorryia gizal El-Bagoury}

Habitats and distribution: Branches of mandarin and lime in Fayoum (Sennores) (Rahil \& Abd-El-Halim, 2000).

\section{Paralorryia mali (Oudemans)}

Habitats and distribution: Branches of mandarin in Fayoum (Sennores) (Rahil \& Abd-El-Halim, 2000).

\section{Paralorryia sp.}

Habitats and distribution: Leaves of Baladi orange and Baladi lemon in Lower Egypt (Rasmy et al., 1972).

\section{Paratriphytydeus sp.}

Habitats and distribution: Leaves of Baladi orange in Lower Egypt (Rasmy et al., 1972).

\section{Pronemtus rykei Meyer \& Rodriguez}

Habitats and distribution: Leaves and branches of sweet orange and mandarin in Fayoum (Sennores) (Rahil \& Abd-El-Halim, 2000).

\section{Pronematus ubiquitus (McGregor)}

Habitats and distribution: Citrus in Assiut (Sahel Saleem, Badary) and Giza (Zaher et al., 1970); orange orchards in Giza and Tahreer (Rasmy, 1970); leaves and fruits of orange, mandarin, lemon, kumquat and grapefruit in Lower Egypt (Rasmy et al., 1972); citrus in North Sinai (Areish, Rafah), South Sinai (St. Cathrin, Wadi El-Tarfa) and Red Sea (Ras-Ghareb) (Zaher, 1984b); leaves of lime in Fayoum (Sennores) (Rahil \& Abd-El-Halim, 2000).

\section{Tydeus californicus (Banks)}

Habitats and distribution: Citrus orchards in Giza (Zaher et al., 1970); leaves and fruits of orange, mandarin, lemon, kumquat and grapefruit in Lower Egypt (Rasmy et al., 1972); citrus trees (Rizk et al., 1978-1979); citrus in North Sinai (Areish, Rafah) (Zaher 1984b); leaves and branches of sweet orange, mandarin and lime in Fayoum (Sennores) (Rahil \& Abd-El-Halim, 2000).

\section{Tydeus kochi Oudemans}

Habitats and distribution: Cosmopolitan in citrus orchards (Zaher et al., 1970); orange orchards in Giza and Tahreer (Rasmy, 1970); leaves of Baladi orange in Lower Egypt (Rasmy et al., 1972); citrus in North Sinai (Areish, Rafah) and Red sea (Ras-Ghareb) (Zaher, 1984b); leaves and branches of mandarin and lime in Fayoum (Sennores) (Rahil \& Abd-El-Halim, 2000).

\section{Tydeus lambi Baker}

Habitats and distribution: Citrus in South Sinai (St. Cathrin) (Zaher 1984b).

\section{Tydeus spp.}

Habitats and distribution: Citrus sinensis in Giza (Zaher \& El-Badry, 1962); leaves of lime, orange and mandarin in Assiut (Salman et al., 1975).

\section{ORDER CRYPTOSTIGMATA}

Family: Galumnidae Jacot

133. Galumna sp.

Habitats and distribution: Citrus orchards in Tahreer (Zaher et al., 1970).

\section{Pilogalumna sp.}

Habitats and distribution: Soil under citrus in Dakahlia and Giza (Zaher, 1986).

\section{Family Haplozetidae Grandjean}

135. Perxylobates obesus Bayoumi

Habitats and distribution: Soil under citrus in Alexandria and Beheira (Zaher, 1986).

136. Rostrozetes citri Nasr \& Hassan

Habitats and distribution: Debris under citrus in Monufia and Qalyubia (Zaher, 1986).

137. Xylobates souchnaiensis Abdel Hamid

Habitats and distribution: Soil under orange in Qena, 
Assiut, Beheira and Gharbia (Zaher, 1986).

\section{Family: Oribatulidae Thor}

\section{Oribtula sp.}

Habitats and distribution: Citrus trees (Hashem et al., 1987).

\section{Siculobata sicula (Berlese)}

Habitats and distribution: Leaves and fruits of orange, mandarin, lemon, kumquat and grapefruit in Lower Egypt (Rasmy et al., 1972); cosmopolitan on citrus trees (Zaher, 1986).

140. Zygoribatula sayedi El-Badry \& Nasr

Habitats and distribution: Soil under citrus in Giza, Beni Suef and Monufia (Zaher, 1986).

\section{Family: Phthiracaridae Perty}

\section{Euphthiracarus sp.}

Habitats and distribution: Citrus orchards in Giza (Zaher et al., 1970).

\section{Family: Scheloribatidae Grandjean}

\section{Liebstadia sp.}

Habitats and distribution: Cosmopolitan in citrus orchards (Zaher et al., 1970); leaves and fruits of orange, mandarin, lemon, kumquat and grapefruit in Lower Egypt (Rasmy et al., 1972).

\section{Scheloribates sp.}

Habitats and distribution: Citrus orchards in Assiut (Sahel Saleem) (Zaher et al., 1970); leaves and fruits of orange, mandarin, lemon, kumquat and grapefruit in Lower Egypt (Rasmy et al., 1972).

\section{Family: Sphaerochthoniidae Grandjean}

\section{Sphaerochthonius transversus Wallwork} Habitats and distribution: Branches of lime in Fayoum (Sennores) (Rahil \& Abd-El-Halim, 2000).

\section{ORDER ASTIGMATA}

\section{Family: Acaridae Ewing \& Nesbitt}

145. Rhizoglyphus sp.

Habitats and distribution: Citrus orchards in Qalyubia (Banha) (Zaher et al., 1970); leaves and fruits of Baladi orange in Lower Egypt (Rasmy et al., 1972).

\section{Tyrophagus putrescentiae (Schrank)}

Habitats and distribution: Leaves and fruits of lemon (Rasmy et al., 1972); leaves and branches of sweet orange, mandarin and lime in Fayoum (Sennores) (Rahil \& Abd-El-Halim, 2000).

\section{Tyrophagus sp.}

Habitats and distribution: Cosmopolitan in citrus orchards (Zaher et al., 1970).

\section{Family: Hemisarcoptidae Oudemans}

\section{Hemisarcoptes malus (Shimer)}

Habitats and distribution: Citrus trees in Giza, Qalyubia and Monufia (Zaher, 1986); citrus orchards in Cairo, Giza and Beni Suef (Kandeel \& Nassar, 1986).

\section{Family: Histiostomatidae Berlese}

149. Histiostoma sp.

Habitats and distribution: Citrus orchards in Giza (Zaher et al., 1970).

\section{REFERENCES}

Abbasova, E.D. 1972. Phytoseiid mites (Parasitiformes: Phytoseiidae) of Azerbaijan. Avtoreferat Dissertatsii na Soiskanie Uchenoy Stepeni Kandidata Biologicheskikh Nauk. Akadrmiya Nauk Azerbaydzhanskoy SSR, Institut Zoologii, Baku, Azerbaijan, 34 pp.

Abo-Korah, S.M. 1980-1981. Survey and population density of the tarsonemine mites under citrus trees in Monoufeia Governorate, Egypt. Bulletin de la Société Entomologique d'Égypte, 63: 13-18.

Abo-Shnaf, R.I.A. and Moraes, G.J. de. 2014. Phytoseiid mites (Acari: Phytoseiidae) from Egypt, with new records, descriptions of new species, and a key to species. Zootaxa, 3865(1): 1-71.

Attiah, H.H. 1967. The genus Eutetranychus in U.A.R., with description of three new species (Acarina: Tetranychidae). Bulletin de la Société Entomologique d'Égypte, 51(11): 11-16.

Attiah, H.H. 1969. The Tetranychini of the U.A.R. The genus Tetranychus Dufour (Acarina: Tetranychidae). Acarologia, 11(4): 733-741.

Chant, D.A. and McMurtry, J.A. 2007. Illustrated keys and diagnoses for the genera and subgenera of the Phytoseiidae of the world (Acari: Mesostigmata). Indira Publishing House, West Bloomfield, USA, $220 \mathrm{pp}$.

Chant, D.A. and Yoshida-Shaul, E. 1982. A world review of the soleiger species group in the genus Typhlodromus Scheuten (Acarina: Phytoseiidae). Canadian Journal of Zoology, 60: 3021-3032.

Chant, D.A. and Yoshida-Shaul, E. 1986. A new subfamily, Cydnodromellinae, in the family Phytoseiidae (Acari: Gamasina). Canadian Journal of Zoology, 64: 2811-2823.

Chant, D.A. and Yoshida-Shaul, E. 1987. A world review of the pyri species group in the genus Typhlodromus Scheuten (Acari: Phytoseiidae). Canadian Journal of Zoology, 65; 1770-1804.

Dosse, G. 1972. Uber einige Tenuipalpiden (Acari, Tenuipalpidae). Pfl anzenschutzberichte, 43(1/2): 1-11. 
El-Badry, E.A. 1967. Five new phytoseiid mites from U.A.R., with collection notes on three other species (Acarina: Phytoseiidae). Indian Journal of Entomology, 29: 177-184.

El-Badry, E. A. 1968. Some predatory mites of the genera Typhlodromus and Amblyseius from the United Arab Republic (Acarina: Phytoseiidae). The Entomologist, 101: 139-144.

El-Badry, E. A. and Zaher, M. A. 1960. First record on some predator mites of family Cheyletidae in Egypt (Acarina). Bulletin de la Société Entomologique d'Égypte, 44: 287-290.

El-Banhawy, E. M.; El-Borolossy, M. A.; El-Sawaf, B. M. and Afia, S. I. 1997. Biological aspects and feeding behaviour of the predacious soil mite Nenteria hypotrichus (Uropodina: Uropodidae). Acarologia, 38(4): 357-360.

El-Halawany, M. E. 1991. Some factors affecting the distribution of Brevipalpus californicus (Banks) on citrus trees. Egyptian Journal of Agricultural Research, 69(1): 185-192.

FAOSTAT. 2008. FAO Statistics Division.

Halawa, A. M. and Fawzy, M. 2014. A new species of Brevipalpus Donnadieu (Acari: Tenuipalpidae) and key to the Egyptian species. Zootaxa, 3755(1): 87-95.

Hashem, M.; Helal, E.; El-Gayar, F. and Farah, E. E. M. 1987. Some biological studies on the beetle mite Oribatula sp. (Acarina: Oribatulidae). Alexandria Journal of Agricultural Research, 32(3): 369-377.

Kandeel, M. M. H. and El-Halawany, M. E. 1985. A new predatory mite species, Typhlodromus kadii (Acarina: Phytoseiidae) in Egypt. Proceedings of Egypt's National Conference on Entomology, 1: 463-468.

Kandeel, M. M. H. and El-Halawany, M. E. 1986. A new mite species, Amblyseius aegyptocitri n. sp. (Acari: Phytoseiidae) in Egypt. Bulletin de la Société Entomologique d'Égypte, 66: 1-4.

Kandeel, M.M.H. and Nassar, O. A. 1986. Field observations on the predatory mites of citrus pests along with a key to the Egyptian species (Acari). Bulletin de la Société Entomologique d’Égypte, 66: 169-176.

Kandeel, M.M.; Rakha, M.A. and El-Halawany, M.E. 1986. Citrus mites in Egypt. Agricultural Research Review, 64(1): 123-127.

Kanouh, M.; Kreiter, S.; Douin, M. and Tixier, M. S. 2012. Revision of the genus Neoseiulella Muma (Acari: Phytoseiidae). Re-description of species, synonymy assessment, biogeography, plant supports and key to adult females. Acarologia, 52: 259-348.

Khanjani, M. and Ueckermann, E. A. 2002. The stigmaeid mites of Iran (Acari: Stigmaeidae). International Journal of Acarology, 28: 317-339.
Mohamed, I. I. 1965. Host preference of the citrus brown mite Eutetranychus banksi (McGregor). Bulletin de la Société Entomologique d'Égypte, 48: 163-170.

Negm, M.W. and Mesbah, A. E. 2014. Review of the mite family Cheyletidae (Acari:

Trombidiformes: Cheyletoidea) of Egypt. International Journal of Acarology, 40(5): 390396.

Rahil, A.A.R. and Abd-El-Halim, S.M. 2000. Survey and population studies of dominant mites associated with three citrus species at Fayoum Governorate. Menofia Journal of Agricultural Research, 25(5): 1241-1253.

Ramadan, H.A.I.; El-Banhawy, E.M. and Afia, S.I. 2009. On the identification of a taxa collected from Egypt in the species sub-group andersoni: morphological relationships with related species and molecular analysis of inter and intra-specific variations (Acari: Phytoseiidae). Acarologia, 49: 115-120.

Rasmy, A.H. 1970. Relation between predacious and phytophagous mites on citrus. Zeitschrift für Angewandte Entomologie, 67(1/4): 6-9.

Rasmy, A.H.; Zaher, M.A. and Albagoury, M.E. 1972. Mites associated with citrus in the Nile Delta (U.A.R.). Zeitschrift fürAngewandte Entomologie, 70: 183-186.

Rizk, G.A.; Karaman, G.A. and Ali, M.A. 1978-1979. Population densities of phytophagous and predacious mites on citrus trees in Middle Egypt. Bulletin de la Société Entomologique d'Égypte, 62: 97-103.

Romeih, A.H.M. and Abo-Shnaf, R.I.A. 2006. A new species of the Genus, Neocunaxoides (Acari: Cunaxidae) in Egypt. Journal of Agricultural Sciences Mansoura University, 31(12): 76017607.

Romeih, A.H.M.; Hassan, M.F.; Rizk, M.A. and AboShnaf, R.I.A. 2005. Description and life history of Typhlodromus citri Hassan \& Romeih sp.n. (Acari: Phytoseiidae). Egyptian Journal of Biological Pest Control, 15(1/2): 49-56.

Romeih, A.H.M.; Hassan, M.F.; Rizk, M.A. and AboShnaf, R.I.A. 2010. Egyptian checklist of mites from aromatic, medicinal and ornamental plants. Acarines, 4: 37-46.

Salman A.G.A.; Negm, A.A.; Abou-Ghadir, M.F.; Ali, A.M. and Darwesh, A.Y. 1975. Seasonal trends of citrus mites, Eutetranychus orientalis (Klein) and Brevipalpus phoenicis (Geijskes), and the role of predaceous mites, total nitrogen and total carbohydrates in relation to degree of infestation of citrus trees. Assiut Journal of Agricultural Sciences, 6(4): 127-140.

Sayed, M.T. 1942. Contribution to the knowledge of Acarina of Egypt. IV. The 
Genus Anychus McGregor [Tetranychidae]. Bulletin de la Societe Fouad ${ }^{\text {er }}$ Entomologique, 26: $125-131$.

Sayed, M.T. 1946. The genus Anychus McGregor in Egypt and the Sudan [Acarina: Tetranychidae]. Bulletin de la Societe Fouad $\mathrm{I}^{\text {er }}$ Entomologique, 30: 143-148.

Soliman, Z.R. and Abou-Awad, B.A. 1978. Five new species of the genus Eriophyes in the A.R.E. (Acarina: Eriophyoidea: Eriophyidae). Acarologia, 19(4): 668-677.

Vacante, V. 2010. Citrus Mites: Identification, Bionomy and Control. Wallingford: CABI Publishing. $378 \mathrm{pp}$.

Wafa, A.K. and Soliman, Z.R. 1968. Five genera of family Cheyletidae (Acarina) in the U.A.R. with a description of four new species. Acarologia, 10: 220-229.

Wysoki, M. and Bolland, H.R. 1983. Chromosome studies of phytoseiid mites (Acari: Gamasida).International Journal of Acarology, 9: 91-94.

Zaher, M.A. 1984a. Survey and Ecological Studies on Phytophagous, Predaceous and Soil Mites in Egypt. 1. Phytophagous mites in Egypt (Nile Valley and Delta). PL. 480 Programme U.S.A., Project No. EG-ARS 30. Grant No. FG-EG 139. $228 \mathrm{pp}$.

Zaher, M.A. 1984b. Survey and Ecological Studies on Phytophagous, Predaceous and Soil Mites in Egypt. III. Mites of Sinai. PL. 480 Programme U.S.A., Project No. EG-ARS 30. Grant No. FG-EG 139. 36 pp.

Zaher, M.A. 1986. Survey and Ecological Studies on
Phytophagous, Predaceous and Soil Mites in Egypt. II-A: Predaceous \& Nonphytophagous Mites (Nile Valley and Delta). Text. PL. 480 Programme U.S.A., Project No. EG- ARS 30, Grant No. FG- EG 139. 567 pp.

Zaher, M.A. and El-Badry, E.A. 1962. Abundance of mites and insects predaceous on tetranychid and tenuipalpid mites in Giza. Bulletin de la Société Entomologique d'Egypte, 46: 429-441.

Zaher, M.A. and El-Badry, E.A. 1964. Survey and population studies on red and false spider mites. Acarologia, Fasc. H.S.: 425-433. (1 $1^{\text {st }}$ International Congress of Acarology, Fort Collins, Colorado, U.S.A.).

Zaher, M.A. and Gomaa, E.A. 1979. Three new species of the genus Raphignathus in Egypt (Prostigmata: Raphignathidae). Acarologia, 21(2): 187-203.

Zaher, M.A. and Shehata, K.K. 1970. A new typhlodromid mite Typhlodromus tetramedius. Bulletin de la Société Entomologique d'Egypte, 54: 117-121.

Zaher, M. A. and Soliman, Z. R. 1965. Eutogenes punctata $\mathrm{n}$. sp. (Acarina: Cheyletidae). Bulletin de la Société Entomologique d'Egypte, 49: 65-66.

Zaher, M. A.; Gomaa, E. A. and El-Enany, M. A. 1982. Spider mites of Egypt (Acari: Tetranychidae). International Journal of Acarology, 8: 91-114.

Zaher, M.A.; Wafa, A.K.; Ali, M.M. and Rasmy, A.H. 1970. Survey of mites associated with citrus trees in Egypt and Gaza Strip. Bulletin de la Société Entomologique d'Egypte, 54: 73-79. 